\title{
GENDERED NARRATIVES AND FEMININE IDENTITY FORMATION IN MEDIA PERSONAL ACCOUNTS
}

\author{
(Narrativas de gênero e formação de identidades femininas \\ em relatos pessoais midiáticos)
}

Débora de Carvalho Figueiredo (Programa de Pós-Graduação em Ciência da Linguagem- UNISUL-SC)

\begin{abstract}
In late modernity, the concepts of identity and identity formation have become inseparable from language and discourse. In this article, based on the theoretical frameworks of Critical Discourse Analysis (CDA), Identity Studies, Narrative Studies and Genre Studies, I investigate how the identities of three women, especially in what concerns their body design, is construed in the genre 'media personal accounts', in the present case accounts of experiences of cosmetic plastic surgery published in two Brazilian glossy magazines, Claudia and Plastic Surgery\&Beauty (Plástica\&Beleza).
\end{abstract}

Key-words: feminine identity formation; narrative studies; critical discourse analysis

\section{RESUMO}

Na modernidade tardia, os conceitos de identidade e formação de identidades tornaram-se inseparáveis da linguagem e do discurso. Neste artigo, com base nas abordagens teóricas propostas pela Análise Crítica do Discurso (ACD), pelos Estudos sobre a Identidade e pelos Estudos de Gênero, investigo como as identidades de três mulheres, em especial no que concerne seus desenhos corporais, são construídas no gênero textual "relato pessoal midiático", no presente trabalho representado 
por relatos de experiências pessoais de cirurgia plástica cosmética publicados em duas revistas femininas brasileiras, Claudia e Plástica \& Beleza.

Palavras-chaves: análise crítica do discurso; estudos da narrativa; formação de identidades femininas; revistas femininas.

\section{Introduction}

In late modernity, the concepts of identity and identity formation have become inseparable from language and discourse. As scholars both in the area of linguistics and of social sciences affirm, identities are forged within discourse, more specifically within socially and institutionally situated discursive practices (Fairclough, 1992, 2003, 2006; Moita Lopes, 2001; Hall, 1996; Bruner, 1990, 2004; etc.).

Recent social phenomena/movements such as the liberation of women, of gays/lesbians, of blacks, etc., have helped to open up spaces for discussion and theorization about who we are in social life (Moita Lopes, 2001, p. 56). In late modernity, media discourses (of television, cinema, print media, the internet), by presenting human experience under multiple and plural forms, register and publicize the constant changes that are taking place in social life. However, as Moita Lopes (2001, p. 55) points out, there is an ever-present danger that information technologies, working for a neoliberal globalized discourse, might erase "the differences we are made of". This is precisely one of the points I want to explore in this article: the fact that, at the same time that the mass media offer us windows through which we can glance at different possibilities of being and living, they also work to impose hegemonic models of identity, be them in terms of gender, sexuality, human relations, or body design. 


\section{Theoretical Background}

In this article, based on the theoretical frameworks of Critical Discourse Analysis (CDA), Identity Studies, Narrative Studies and Genre Studies, I investigate how the identities of three women, especially in what concerns their body design, is construed in the genre of media personal accounts, in the present case of experiences of cosmetic plastic surgery (from now on CPS) published in two Brazilian glossy magazines, Claudia and Plastic Surgery\&Beauty (Plástica\&Beleza). My main contention in this work, in terms of genre, is that certain genres of the media (such as media personal accounts) perform the social action of creating idealized identities that interpellate and imbricate individuals by and into gendered narratives.

\subsection{Narrative and identity formation}

According to researchers from different areas of the Social Sciences, narrative, as a discursive form of acting in the world, plays a central role in the construction of social identities

According to Bruner (2004), for human beings lived time can only be described in narrative form. Life narratives are sociocognitively constructed by human beings through language. In this sense, life itself is a socio-cognitive human construction. As the author puts it, "narrative imitates life, life imitates narrative. [...] There is no such thing as 'life itself'. At the very least, [life] is a selective achievement of memory recall; beyond that, recounting one's life is an interpretive feat" (Bruner, 2004, pp. 692-693).

The focus of scholars such as Bruner and Moita Lopes is the role of narrative as an organizing element of discourse and, by extension, of knowledge, identities and social relations. Narratives are not just ways to build certain views of reality. As spaces of struggle for the legitimation of specific meanings and representations, they also represent forms of controlling and manipulating reality and 
the participants of discursive events. In identity terms, narratives legitimate and privilege certain forms of subjectivities while excluding others.

\subsection{Narrative and genre}

Fairclough defines genres as discursive aspects of the way people act and interact in social events (2003, p. 65). That is, genres are particular forms of social relations between social agents (individuals or organizations). From the point of view of CDA, therefore, genre analysis focuses on the role played by genre in establishing social action/interactions in social events.

The texts under analysis in this article are probably part of a category of genres which could be called personal stories narrated in the first person. They are primarily discoursal, and their basic purpose is to give strength, vividness and credibility to an array of hegemonic discourses, sometimes in an openly promotional form (e.g. in websites of plastic surgery clinics which present personal accounts of ex-clients, always satisfied with the results of the cosmetic procedures/surgeries underwent), sometimes in a less overtly promotional form, aiming at circulating, strengthening and legitimizing a certain ideology (e.g. oral personal accounts given by participants of groups such as the Weight Watchers, the AA, churches and religious sects). If we say that the main communicative purpose of personal accounts in general is, explicitly, to illustrate a certain point in a discussion, we could also claim that there is a secondary purpose (generally implicit) which gives these texts a strong ideological character: many of them are used for promotional aims, or as a way of adding vividness, legitimacy, veracity and credibility to the discourse where they occur (e.g. the discourse of women's magazines).

Media personal accounts, though apparently communicative (i.e. aiming at transmitting someone's personal experience to the readers, and thus illustrating a point in an argument), are in fact 
strategic in the sense that they also help to 'sell' specific ideas, products and services (in the present case, cosmetic procedures and surgeries advertised by the magazines). This can be seen as ideological since it legitimizes the 'pathological' (Habermas, 1984) invasion of the lifeworld (the world of everyday experience) by systems and instrumental rationality (Fairclough, 2003). This blurring of communicative and strategic purposes in media personal accounts of CPS indicates that women's magazines mediate information on CPS between expert systems (doctors, clinics, pharmaceutical companies, who are their advertising clients) and the lay readers, thus shaping our knowledge of CPS and gearing it towards market ends.

\section{Analytical Procedures}

In any mass media personal account, the text is supposedly a tale told by a real person who, prior to the act of telling her story, has undergone some personal experience worth telling and worth reading about. This is what Labov and Waletsky (1967) called "reportability", that is, the success of any narrative depends on it having a 'point' and a reason to be told.

Lavob proposed, in his 1972 essay, a structural model for the analysis of fully-formed oral narratives, which I will apply to my data:

1. Abstract: What is the story about?

2. Orientation: Who, when, where, what?

3. Complicating action: Then what happened?

4. Evaluation: So what, how is this interesting?

5. Result or resolution: What finally happened?

6. Coda: That's it, I've finished.

In addition to the Labovian model described above, I am also applying to the analysis of these narrative texts the macro- 
analytical model of “problem-solution” developed by Hoey (1979, 1983).

Finally, to add a socio-discursive turn to the micro-analysis of my data, I am also making use of van Leeuwen's (1996) model for the analysis of social actors (coupled with some categories from Halliday's (2004) systemic functional grammar). In his model, van Leeuwen proposes a network of sociosemantic systems to investigate how social actors are represented in discourse.

\section{Analytical Section}

\subsection{Move II: Orientation - Resources used in the narrators' 'self' representation}

Since the theme of each of these media personal accounts is the main character's discontentment with her body shape, her representation requires a description of physical traits. This form of representation is what van Leeuwen calls 'physical identification', which depicts social actors "in terms of physical characteristics which uniquely identify them in a given context. It can be realized by nouns denoting physical characteristics [...] or by adjectives [...] or prepositional phrases [...]" (1996, p. 57). This is how the narrators supposedly described themselves physically:

(9) [...] during adolescence I began to consider myself fat. When I turned 23, I was far from my ideal weight. [...] ("My diary: your story with the scalpel" - Plastic Surgery\&Beauty, Nov. 2006, p. 42)

(10) But when I got the invitation from the [Cristal soap opera] production team, I started to worry about my projecting tummy. ("Celebrity Cosmetic Surgery - the secret for a perfect shape” - Plastic Surgery\& Beauty, Nov. 2006, p. 44) 
(11) But, as my best friend said, what's the good of spending a week in Salvador with a flat chest? [But] after losing weight, the little [breast] I had disappeared, and I started missing them, especially in summer. ("Silicon Diary" - Claudia, Oct. 2006, p. 202)

Different from other forms of role allocation, physical identification is always overdetermined. In the excerpts above, this overdetermination is always negative, creating the image of the narrator's dissatisfaction with at least some aspect of her body shape. The physical attributes focused on in the excerpts above legitimize and reinforce the hegemonic feminine model of the slim, fit and curvaceous body. In the excerpts, the women's bodies are fragmented, and some of their parts (the belly, the hips, the breasts) are given focal status as a part that epitomizes the ideal of female beauty and physical attractiveness: a flat belly, curvaceous hips (examples 9 and 10) and large, firm (or at least clearly visible) breasts (example 11). The use of physical identification is never neutral in the representation of social actors, and it can be used, as in Claudia and Plastic Surgery\&Beauty's media personal accounts of CPS, to focus the reader's attention on selected physical traits that objectify the narrators as sexual commodities.

In the accounts analysed, most of the elements of the orientation move (the participants and the circumstances) follow the linear pattern of narrative genres, coming after the abstract and before the complicating action (Labov, 1972). Besides being described in terms of their physical traits, as we have seen above, another resource used by the narrators to refer to themselves is the representation of people around them. The women narrators, apart from the description of their bodies, are also identified through their relations with social actors from the private and the public spheres of their lives: friends, fiancée, husband, children, work colleagues, boss:

(12) Last April I got engaged and we decided to get married next year. I started to analyse my situation and $\emptyset$ realized that 
I couldn't get married with this body. ("My diary: your story with the scalpel" - Plastic Surgery\&Beauty, Nov. 2006, p. 42) (13) But when I got the invitation from the [Cristal soap opera] production team, I started to worry about my projecting tummy. ("Celebrity Cosmetic Surgery - the secret for a perfect shape” - Plastic Surgery\&Beauty, Nov. 2006, p. 44)

(14) I remember the first time that, half kidding, I talked to my husband [about the breast enlargement operation]. Ricardo gave me a big smile and surprised me with a nice 'and why not?' If I had one motive, he had ulterior ones. [...] After that I could swear that every time Ricardo looked at me he saw a small sign saying: 'Soon playground here'. ("Silicon Diary” - Claudia, Oct. 2006, p. 202)

The use of relational identification indicates that, even though the first-person female narrators are nominated and functionalized (their full names and professions are given), their social relations are also a central aspect of their identities, especially in what concerns their body shape, since it is through the impact of their images on others, through the gaze of the Other (especially a male Other) over their bodies, that they construct their self-identities. Notice that, in all of the examples above, the reactions of the social actors who surround the narrator (both privately and publicly) seem to have been essential in their decision to undertake a CPS, either as sources of encouragement and stimulation or as representatives of the outside, hegemonic gaze that helps to shape and establish, even for the narrators themselves, the ideal of feminine beauty and bodily attraction.

\subsection{Move III: Complicating Action}

The media personal accounts analysed in this article follow the formulaic pattern of beginning with a situation seen as problematic by 
the narrator (Hoey, 1979; 1983), which corresponds to the Labovian move of orientation:

(19) I dance ballet since I was four years old and during adolescence I began to consider myself fat. When I turned 23, I was far from my ideal weight. My self-esteem went down, my clothes didn't look good, and I began to get mad at any little thing [...] Last April I got engaged and we decided to get married next year. I started to analyze my situation and $\emptyset$ realized that I couldn't get married with this body. ("My diary: your story with the scalpel” - Plastic Surgery\&Beauty, Nov. 2006, p. 42)

(20) Before thinking about changing my appearance, I used to eat anything. But when I got the invitation from the [Cristal soap opera] production team, I started to worry about my projecting tummy. As I had little time until the beginning of the shootings, there was no point in going to the gym because the problem wouldn't disappear overnight" ("Celebrity Cosmetic Surgery - the secret for a perfect shape" - Plastic Surgery\&Beauty, Nov. 2006, p. 44)

(21) I am a Libra like Cláudia. When you read this anniversary edition, I will be enjoying the big present I gave myself for my 39th birthday: new boobs. Yes, I could have chosen a dress, a bag, a trip. But, as my best friend said, what's the good of spending a week in Salvador with a flat chest? [...] after losing weight, the little [breast] I had disappeared, and I started missing them, especially in summer. To use a metaphor, it was like redecorating the whole house and leaving a little corner out. ("Silicon Diary" - Claudia, Oct. 2006, p. 202)

The 'problem' is always related to the fact that the narrator's figure did not conform, before the CPS, to the hegemonic model of the slim and curvaceous body. 
The presentation of the problem is followed by the move complicating action (Then what happened?), which is the essence of the narrative (Labov, 1972). The problematic situation described by the narrators (their unhappiness with some aspect of their body shape) is dealt with through a series of actions:

(22) I decided to do a liposuction on my abdomen and sides to get faster and more efficient results. I went to a plastic surgeon and liked him immediately. [...] I cleared all my doubts before the surgery and waited for the day of the operation. [...] I had no regrets whatsoever. ("My diary: your story with the scalpel - Plastic Surgery\&Beauty, Nov. 2006, p. 42)

(23) I went to a specialist in Aesthetic Medicine, dr. Eliomar Jayme (RJ) and I did a hydro-liposuction to remove some extra fat from my sides and abdomen. ("Celebrity Cosmetic Surgery - the secret for a perfect shape" - Plastic Surgery\&Beauty, Nov. 2006, p. 44)

(24) Surfing the web, I discovered an array of possibilities. [...] I took that information in and my brain gently transformed it into generous cleavages, tank tops, bottomless shirts. [...] I decided to surrender myself to the scalpel [...] Oh, the first appointment. [...] The only thing I didn't expect was being nervous. [...] Finally the day arrived and I was calm. The surgery lasted less than two hours and I went back home on the same day. ("Silicon Diary" - Claudia, Oct. 2006, p. 202)

In these actions the narrators represented themselves as "the active, dynamic forces in the activity", what van Leeuwen calls "activation". In the excerpts above the narrators represent themselves as actors in material processes ( $I$ did a hydroliposuction, I went to a plastic surgeon, I waited, I went back home), sensors in mental processes (I decided to do a liposuction, I cleared all my doubts, I had no regrets, I discovered an array 
of possibilities, I took that information in, I decided to surrender myself to the scalpel), and carrier in a relational process (I was calm). Even though the narrators are actors of material processes, in semantic terms some of these processes are in fact carried out by other people, not by the narrator herself (such as in 'do a hydro-liposuction' and even 'go to a plastic surgeon'). In both these cases, the doctor is in fact the one who, once chosen by the patient, provides information on CPS and actually performs the operation. The mental processes (I decided to do a liposuction, I decided to surrender myself to the scalpel, I discovered an array of possibilities, I took that information in) seem to indicate that, even though the first-person narrator is the agent of these actions, they are not concrete actions in the 'real' world, rather they represent a 'master narrative' the narrator constructs for herself, a series of mental decisions that precede the surgical intervention and which have to do with how the narrator sees herself and wishes to be seen by others. These mental processes, coupled with the material processes which are in fact performed by others upon the narrators, represent the identity projected for each of these narrators: a woman who is concerned with her body shape, who concludes that her body is not 'adequate' and, consequently, gives her body up into the hands of professionals (e.g. plastic surgeons) who can 'correct', re-shape and align it with the hegemonic model of female beauty. In short, these first-person narrators construe themselves (or are construed) semiotically and symbolically, while others construct (or re-construct) them physically.

\subsection{Move IV: Evaluation}

The evaluation is a very important element in any type of narrative genre. From a critical perspective, the evaluative elements in narrative genres are extremely relevant because it is mainly through them that the narrator will express her ideological stance(s) towards the story she is recounting. 
In the exemplars of media personal accounts analyzed here, all the three narrators positively evaluate the surgical procedure they underwent:

(25) The operation was great and I didn't feel any discomfort. I'm extremely happy and anxious for the bikini test since this will be my first summer with my new silhouette! ("My diary: your story with the scalpel - Plastic Surgery\&Beauty, Nov. 2006, p. 42)

(26) To maintain the results, I do sessions of lymphatic draining, in addition to modeling massage, endermology and carboxitherapy at the Vitalitá Clinic (SP). Besides, I work out an hour and a half everyday: I do the treadmill or spinning, yoga or Pilates. And my diet has changed completely! My meals are rich in salads, vegetables and fruit. After my full recovery and as soon as I find some free time, I intend to have a breast enlargement surgery ("Celebrity Cosmetic Surgery - the secret for a perfect shape" - Plastic Surgery\&Beauty, Nov. 2006, p. 44)

(27) It didn't hurt a bit. Of course the first thing I did when I woke up was to take a pip [at the breasts] in the recovery room [...] The difference was visible. [...] I was only introduced officially to my new breasts 24 hours later, when I returned to take out the drain. When I opened the bra, they jumped out, happy and exultant. Nice to meet you! And the pleasure was all mine $[\ldots]$ Weighing everything, it was worth it. It's like having recovered something that was mine by right. ("Silicon Diary”-Claudia, Oct. 2006, p. 202)

The narrators talk about happiness and increased self-esteem after their bodies were better aligned with the thin and curvaceous hegemonic model. It is worth noticing that a beautiful and attractive body is construed as a 'right' of the female gender, as we can see in example 27 ("It's like having recovered something that was mine by 
right"). Also worthy of notice is the way this same narrator indicates that the gaze of the Other (usually Man) is an important measure of female beauty and value ("I found out that size does matter"): the premise here is that, to be beautiful and attractive, women have to be seen, and to be seen they have to possess the 'right' physical proportions in the 'right' places - curvaceous hips, small waist, large and firm breasts. Otherwise, they become socially invisible.

\section{Concluding Remarks}

In the cases of CPS addressed by the genre media personal accounts analysed in this paper, the narrators are nominated, functionalized and identified through the use of their full names and professions, which help to place them in recognizable social spaces. The professional glossing also seems to attach these narrators to the public rather than to the private world. This media genre seems to attempt at being more 'realistic' and less fictionalized than other media narratives presented as part of larger reportages - e.g. as in Caldas-Coulthard's (1996) study of narratives of sex published by Marie Claire.

However, even though these first-person narrators are represented as professional women who occupy spaces in the public world, their physical appearance is seen as an important measure of their social worth. Their decision to undergo a cosmetic plastic surgery is also grounded on their relations to other social actors, such as partners, friends, colleagues and employers, who seem to function, to these narrators, both as a way of identifying themselves in terms of their network of social relations, and as sources of encouragement and rewards for making every possible effort to fit into the hegemonic model of female beauty and sex-appeal.

Although the genre organization of media personal accounts could allow different approaches to a certain issue (e.g. CPS), the exemplars analysed here are evidence that this genre is used to promote hegemonic models of female identity in women's magazines. 
The organization of the media personal accounts analysed, moving from a negative physical description of the narrators to their decision to undergo a CPS to a final positive evaluation of the results of such procedures, is evidence of our training, through mechanisms of manipulation and control of media information, to distinguish between what can be thought and said in terms of our bodies and our identities, what should be silenced and excluded, and how to say what is socially acceptable, how to define/explain/understand ourselves and the world.

Recebido em: setembro de 2009

Aprovado em dezembro de 2009 deborafigueiredo@terra.com.br

\section{References}

Bamberg, M. G. W. (Ed.). (1997). Oral versions of personal experience: Three decades of narrative analysis. Journal of Narrative and Life History. 7 (1-4) - Special Issue.

Bonini, A. (2001). Ensino de gêneros textuais: A questão das escolhas teórica e metodológica. Trabalhos em Lingüística Aplicada. 37, 7-23.

Bruner, J. (2004). Life as narrative. Social Research, 71(3).

Bruner, J. (1990). Acts of meaning. Cambridge, MA: Harvard University Press.

Caldas-Coulthard, C.R. (1996). 'Women who pay for sex. And enjoy it'. Transgression versus morality in women's magazines. In C.R CaldasCoulthard \& M.Coulthard (Eds.), Texts and practices: Readings in critical discourse analysis. London: Routledge.

Duranti, A. (1986). The audience as co-author: An introduction. Text, 6, 239-47.

Fabrício, B. F. (2006). Narrativização da experiência: o triunfo da ordem sobre o acaso. In I. Magalhães, M. J. Coracini \& M. Grigoletto (Eds.), 
Práticas Identitárias: Língua e Discurso. São Carlos: Claraluz.

Fairclough, N. (1992). Discourse and Social Change. Cambridge: Polity Press.

Fairclough, N. (2003). Analysing discourse: textual analysis for social research. London: Routlege.

Fairclough, N. (2006). Language and globalization. London: Routledge. Figueiredo, D.C. (forthcoming) Identidades corporificadas nos discursos midiáticos pós-modernos: os discursos sobre o emagrecimento e a cirurgia plástica. Anais do 7o. Encontro do CELSUL (Círculo de Estudos Lingüísticos do Sul).

Habermas, J. (1984). Theory of communicative action, Vol. 1, London: Heinemann.

Hall, S. (1996). Who needs identity? In S. Hall, \& P. Du Gay (Eds.), Questions of identity. London: Sage.

Halliday, M.A.K. An introduction to functional grammar. 3. ed. London: Edward Arnold, 2004.

Hoey, M. P. (1979). Signalling in discourse. Discourse Analysis Monographs, 6, English Language Research, University of Birmingham.

Hoey, M. P. (1983). On the surface of discourse. London: Allen \& Unwin. Labov, W. (1972). Language in the inner city. University Park, PA: University of Pennsylvania Press.

Labov, W \& Waletsky, J. (1967). Narrative analysis: Oral versions of personal experience. In J. Helm (Ed.), Essays on the verbal and visual arts. Seattle, WA: University of Washington Press.

Meurer, J. L. (2002). Reflexões sobre o ensino: Três perguntas não mistificadoras que você pode aplicar aos textos que traz para a sala de aula. In M.J.D Costa; M.E. Zipser, M.E.; Zanatta, M.\& A. Mendes, A. (Orgs.). Línguas: ensino e ações. Florianópolis: Editora da UFSC.

Mishler, E. (1999). Storylines: Craftartists' narratives of identity. Cambridge: Harvard University Press.

Moita Lopes, L. P. (2001). Práticas narrativas como espaço de construção das identidades sociais: uma abordagem socioconstrucionista. In B. T. Ribeiro, C. C. Lima \& M. T. L. Dantas (Eds.), Narrativa, Identidade e Clínica. Rio de Janeiro: Edições IPUB-CUCA. 
Moita Lopes, L.P. (1999) Perceptions of language in L1 and L2 teacherpupil interaction: the construction of readers' social identities. In C. Schaffner \& A. Wenden (Eds), Language and peace. Amsterdam: Harwood Academic Publishers.

Moita Lopes, L.P. (1998) Discursos de identidade em sala de aula de leitura de L1: a construção da diferença. In I. Signorini (Org.), Lingua(gem) e identidade. Campinas: Mercado de Letras.

Norrick, N. R. (1997). Twice-told tales: Collaborative narration of familiar stories. Language in society, 26(2), 199-220.

Paltridge, B. (1996). Genre, text type, and all the language learning classroom. ELT Journal, 50(3), 237-243.

Schiffrin, D. (1996). Narrative as self-portrait: sociolinguistic constructions of identity. Language and Society Processes, 25(2), 167-203.

Schiffrin, D. (1984). How a story says what it means and does. Text, 4(4), 313-346.

Segal, J. (2007). Breast Cancer Narratives as Public Rhetoric: Genre Itself and the Maintenance of Ignorance. Linguistics and the Human Sciences. Special issue on Genres and Social Ways of Being, Vol 3, No 1.

Sousa (2003). Resistir, a que será que se resiste? O sujeito fora de si. Linguagem em Discurso, 3, special issue, 37-54.

Swales, J. M. (1990). Genre analysis: English in academic and research settings. Cambridge: Cambridge UP.

Van Leeuwen, T. (1996). The representation of social actors. In C.R Caldas-Coulthard \& M. Coulthard (Eds.), Texts and practices: Readings in critical discourse analysis. London: Routledge.

Woodward, K. (1997). Introduction. In K. Woodward (Ed.), Identity and difference. London, Sage. 